\title{
Land in Landscapes Circum Landnám: An Integrated Study of Settlements in Reykholtsdalur, Iceland
}

\author{
Guðrún Sveinbjarnardóttir ${ }^{1,3}$, Ian A. Simpson² , and Amanda M. Thomson ${ }^{2}$
}

\begin{abstract}
The initial settlement of Iceland in the 9th and 10th centuries AD was based on animal husbandry, with an emphasis on dairy cattle and sheep. For this activity, land resources that offered a range of grazing and fodder production opportunities were required to sustain farmsteads. In this paper, the nature of land within the boundaries of settlements in an area of Western Iceland centered on Reykholt, which became the estate of the writer and chieftain Snorri Sturluson in the 13th century, is analysed with a geographical information systems (GIS) approach. The results, combining historical, archaeological, and environmental data with the GIS-based topographic analysis, suggests that, although inherent land qualities seem to have played a part in shaping the initial hierarchy of settlement in the area, it was the acquisition of additional property and of access to resources outside the valley that ultimately pushed Reykholt to the forefront in the hierarchical order.
\end{abstract}

\section{Introduction}

Land-its quality, organization, and management-is an aspect of society-environment relationships that has received little attention until recently in studies of landnám (translated as "land-take"), the period of initial settlement and colonization of Iceland which, according to Íslendingabók (The Book of Icelanders) ${ }^{1}$ and supported by archaeological discoveries, took place in the 9th and 10th centuries AD (Benediktsson 1996, Sveinbjarnardóttir 2004, Vésteinsson 1998). Land organization in southern and western Norway during the Viking and Early Middle Ages, around the time of the Icelandic landnám, was characterised by manortype estates controlled by a small elite and with a larger dependent group retained to work the estate (Stylegar 2002). Similar estates are thought to have emerged in Orkney and Shetland (the Northern Isles) during the Viking Age and Later Medieval Period (Crawford and Balin-Smith 1999, Steinnes 1959). Since Iceland was settled largely from Norway via the Northern Isles, it seems fair to assume that a similar type of land organization was also introduced to Iceland with settlement. Written sources, archaeological surveys, and excavations indicate that the settlement pattern in Iceland was that of individual farmsteads placed at even intervals on the best farming land, with households consisting of a single or several families (Sveinbjarnardóttir 1992, Vésteinsson 1998), similar to today's rural settlement pattern. Supporting zooarchaeological evidence, coupled with remains of animal houses, indicates that subsistence strategies from the outset were largely geared towards a reliance on domestic livestock, initially with the main emphasis on dairy cattle, and then increasingly on sheep (e.g., Amorosi 1996, Hermanns-Auðardóttir 1989).
Appropriate land resources and their use at different times of the year were an essential requirement to support these activities (Vésteinsson et al. 2002). An understanding of the attributes and significance of land during colonization and settlement is therefore vital if we are to recognize the way in which land resources were used to create and maintain social structures. Despite an implicit acknowledgment of the significance of this, there has been little attempt to characterize and explain the role land qualities played during the emergence of the early Icelandic cultural landscape. One aim of this paper is to attempt to establish whether land attributes influenced the initial settlement process and its further development, and what this influence may tell us about social organization in early Iceland.

The study area is centered on the Reykholt estate in Reykholtsdalur, western Iceland, at $21^{\circ} 17^{\prime} \mathrm{W}, 64^{\circ} 40^{\prime} \mathrm{N}$, which has been the focus of the multidisciplinary Reykholt project (www.snorrastofa.is). Extensive archaeological investigations have been carried out at the Reykholt site (e.g., Sveinbjarnardóttir 2005b, 2006). The area is delimited by the Hvítá River to the north and the Reykjadalsá River and Steindórsstaðaöxl and adjoining hills to the south (Figs. 1 and 2) and covers $105.6 \mathrm{~km}^{2}$. It is $21 \mathrm{~km}$ from west to east and $8.5 \mathrm{~km}$ at its widest point north to south.

The area was featured in a recent study of the politics and development of early settlement patterns in Iceland (Vésteinsson et al. 2002), where settlements were divided into three categories based on environmental type and access to resources. This division into settlement types forms the basis for the topographical analysis discussed in this paper. The model is also put to the test, and the question of why Reykholt became the most important and

${ }^{1}$ Institute of Archaeology, University College London, 31-34 Gordon Square, London WC1H OPY, UK. ${ }^{2}$ School of Biological and Environmental Sciences, University of Stirling, Stirling FK9 4LA, Scotland, UK. ${ }^{3}$ Corresponding author - gudrun.s@ucl.ac.uk. 
wealthiest farm in the valley in the medieval period is explored. To achieve our aims, we place topographical (geographical information systems [GIS] based) analyses into a thoroughly researched his- torical (documentary source based), archaeological (excavation and survey based) and environmental (palaeoenvironmental studies based) context from the Reykholtsdalur area.

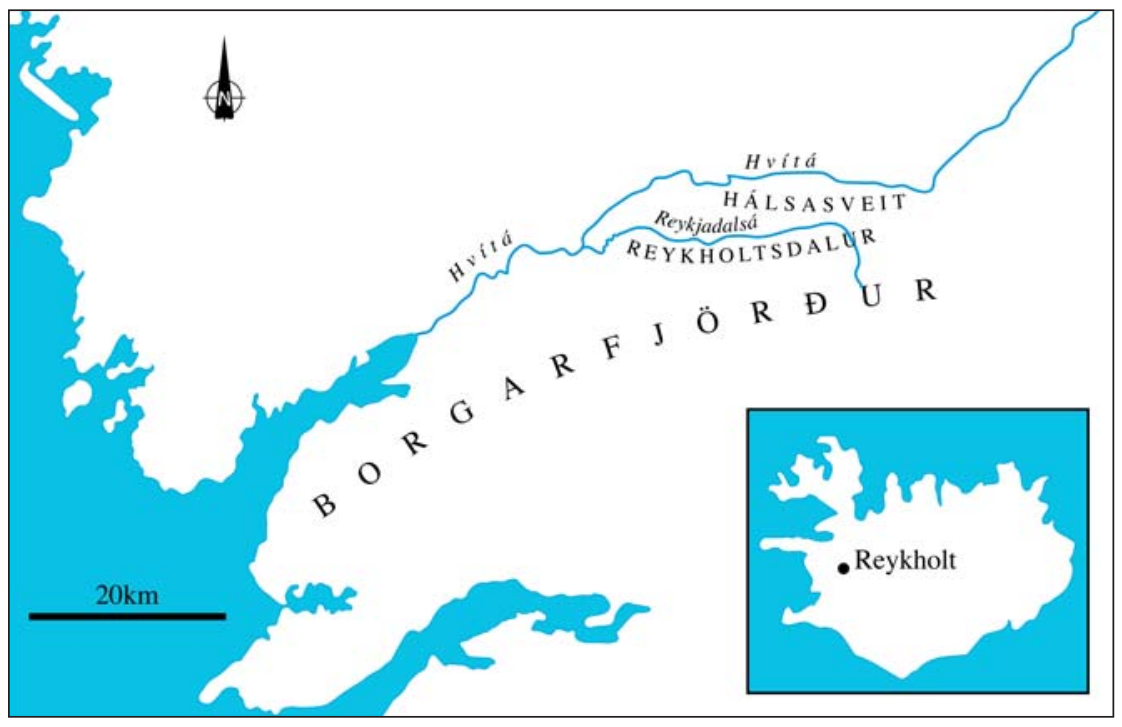

Figure 1. Location of Reykholtsdalur, western Iceland.

\section{Historical analyses}

According to the Book of Settlements (Landnámabók²) and Egil's Saga ${ }^{3}$, the area under consideration formed part of the huge land-take of the chieftain Skallagrímr, one of the earliest settlers in Iceland (Benediktsson 1968:71, Nordal 1933:73-74). He soon gave or sold chunks of this land to other settlers, including one who took the tongue of land between the rivers Hvítá and Reykjadalsá, approximating the study area, and who lived at Breiðabólstaður (13 on Fig. 2; Benediktsson 1968:74).

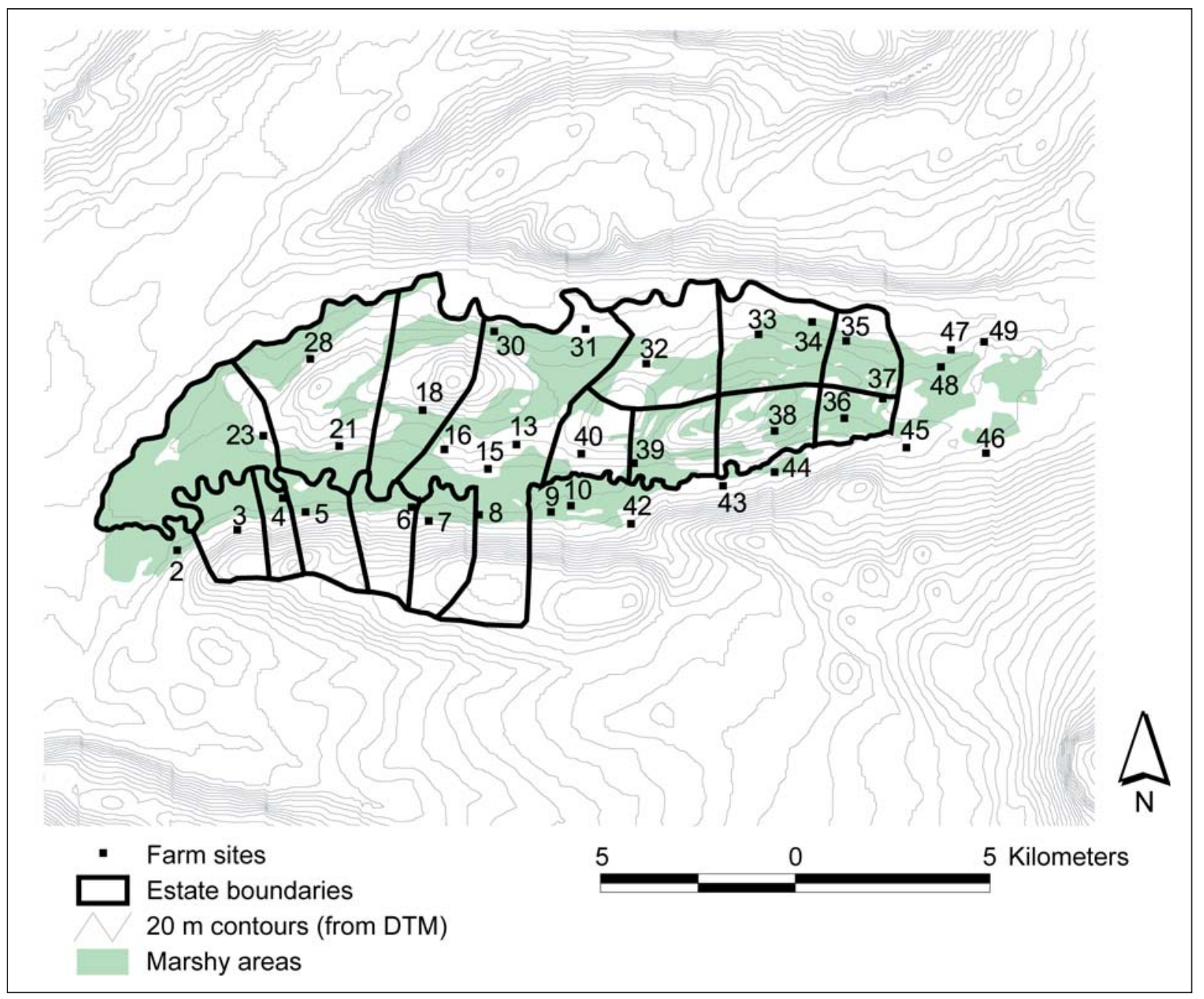

Figure 2. Farm locations and settlement boundaries in the Reykholt region. 
The land in the valley which lies to the south of the Reykjadalsá river formed part of the holdings of two other initial settlers according to Landnámabók and is divided by the gorge Rauðsgil, by which one of them lived (42 on Fig. 2); the other lived in the adjoining valley further south. During subsequent partitioning into farms, this land was divided into a number of holdings, several of which became the property of Reykholt at different times and are therefore included in this study. Our sources for this partitioning of the land are written sources of 12th century date and later, and some archaeological data (Table 1). Despite this lack of direct information about the settlements in the valley before the 12th and 13th centuries, a number of inferences can be made about the earlier settlement history.

The early establishment of the majority of the farmsteads included in this study is supported by indications supplied by the place-name evidence. Of the thirty-four farms (Table 1), twenty have topographic names (thought to be a sign of old age), twelve end in -staðir (a common ending and thought to point to early, important, but secondary farms [Fellows-Jensen 1984:154, 159]), and one suggests a lower status farm (Háfur [30], translated as pocket net, indicating that fishing in the Hvítá river was practiced at this location). The -bólstaður element of what, according to Landnámabók, was the initial farm in the area, Breiðabólstaður (13), is common in Western Norway (Olsen 1928) and the Northern Isles, where it seems to have been active from the beginning of the Viking Age until well into the Medieval Period (Gammeltoft 2001).

Breiðabólstaður (13) is, as already mentioned, named in Landnámabók as the farm of the earliest settler in the area. Reykholt (15) is mentioned by name in Landnámabók as a place attended for baths by the inhabitants of Breiðabólstaður and again as the residence of Dórður Sölvason who lived in the 11th century (Benediktsson 1968:78-9). Archaeological investigations at Reykholt have produced 10th- to 11th-century dates on barley grains for the earliest occupation (Sveinbjarnardóttir et al. 2007). A church, the excavation of which was completed in 2007, seems to have been erected at Reykholt in the 11 th century ${ }^{4}$ or shortly after the introduction of Christianity in about A.D. 1000. It has been suggested that Reykholt had already become a church center (staður) by the early 12th century (Dorláksson 2000). It now seems clear that a church had been established there well before that time. On the basis of the above evidence, it is concluded that Reykholt had been established by c. A.D. 1000 and that it was an important site from the outset.

One indication of this early importance is the fact that by about 1200 the initial farm in the area, Breiðabólstaður (13), belonged to Reykholt, to- gether with the neighbouring farms Hægindi (8) and Norðurreykir (31), with the cottage Háfur (30) being in the care of the church farmer. The earliest preserved charter listing the property of the church at Reykholt is a single sheet of calfskin thought to have been written over the period from the second half of the 12th century until c. 1300 (Gunnlaugsson 2000). The above-mentioned property is not mentioned in the earliest part of the charter, which is dated to the 1180 s. On the other hand, the homeland and extensive rights and privileges in various more distant locations, for grazing, shieling activity, woodland, and driftwood collection, are listed there (Sveinbjarnardóttir 2005b, in press). Grímsstaðir (16), which had become the property of the Reykholt church by 1463 , is mentioned in the 13th-century Sturlunga saga, but the nature of the farm at that time or its earliest history is unknown. In the topographical analysis, it is combined with the land of the Reykholt estate, thus giving the 16th-century picture of its size.

Skáney (18), Sturlureykir (21), and Deildartunga (23) are regarded as having been next in importance. This determination is based on the value of the land they occupied and the fact that all had annex churches in the past, which, based on patterns elsewhere in the country, is an indication of an independent farm established early in the settlement process (Vé-steinsson 1998). Hurðarbak (28) is mentioned in the 13th-century Sturlunga saga, but nothing is known about the nature of the farm at that time or its earliest history. Steindórsstaðir (10), which seems to have had an annex church in the past and lies just outside the study area, also falls into this category.

Along the same lines of inquiry, the remaining 12 settlements within the study area are less important and most only had one farm. They are all mentioned in early sources and are all believed to have been established as secondary farms, although we do not know exactly when or in what order. Háls (37) in the land of Kolslækur (36), together with Vatn (49), in the land of Stóri Ás (47), which lies just outside the study area, were abandoned in the 13th or 14th century. Archaeological investigations have been carried out at Háls, which was never reoccupied (Smith 1995). Research suggests a 10thcentury date for the earliest habitation at the site and an indication that the locale was used as an iron-extraction site in the 9th or early 10th century, before it became a farm. The research also indicated that the area occupied by Kolslækur/Háls (36/37), Sigmundarstaðir (35), Refsstaðir/Bolastaðir (33/34), and Signýjarstaðir (32) was covered with forest or brushwood in the past. There is a reference in a place-name survey for Refsstaðir (The Árni Magnússon Institute for Icelandic Studies-The Place-Name Collection. Hálsasveitarhreppur 3509. Refsstaðir) to charcoal-making in the past in this area which 
lies on the border between the two church seats and large estates, Reykholt and Stóri Ás. The stretch along the Hvítá River, between Stóri Ás (47) and Norðurreykir (30), suffered bad erosion in the past,

Table 1. Earliest settled farms in the Reykholtsdalur area.

\begin{tabular}{|c|c|c|c|c|c|}
\hline $\begin{array}{l}\text { No. } \\
\text { on } \\
\text { map }\end{array}$ & Site name & $\begin{array}{l}\text { Earliest } \\
\text { written } \\
\text { source }\end{array}$ & $\begin{array}{c}\text { Date } \\
\text { (year or } \\
\text { century) }\end{array}$ & $\begin{array}{c}\text { Church / } \\
\text { chapel }\end{array}$ & References and other information \\
\hline 3 & Hamrar & Deed & 1380 & Chapel? & $\begin{array}{l}\text { DI 3:351-2. } \\
\text { Oral tradition. Pétursdóttir 2002:85. }\end{array}$ \\
\hline 4 & Kleppjárnsreykir & Неiðarvíga saga & 12th & & \\
\hline 5 & Snældubeinsstaðir & Sturlunga saga & 13th & & \\
\hline 6 & Kjalvararstaðir & $\begin{array}{l}\text { Landnáma } \\
\text { Charter }\end{array}$ & $\begin{array}{l}12 \text { th } \\
1358\end{array}$ & & DI 3:122-3. Owned by Reykholt. \\
\hline 7 & Kópareykir & $\begin{array}{l}\text { Landnáma } \\
\text { Charter }\end{array}$ & $\begin{array}{l}12 \text { th } \\
1463\end{array}$ & & DI 5:399-400. Owned by Reykholt. \\
\hline 10 & $\begin{array}{l}\text { Steindórsstaðir } \\
\text { Vilmundarstaðir }\end{array}$ & $\begin{array}{l}\text { Charter } \\
\text { Deed }\end{array}$ & $\begin{array}{l}\text { c. } 1185 \\
1550\end{array}$ & Chapel & $\begin{array}{l}\text { DI 1:280. Christian graves found. } \\
\text { Byggðir Borgarfjarðar II:293. } \\
\text { DI 11: 779, } 785 .\end{array}$ \\
\hline 13 & Breiðabólstaður & $\begin{array}{l}\text { Landnáma } \\
\text { Charter }\end{array}$ & $\begin{array}{l}\text { 12th } \\
1206\end{array}$ & & $\begin{array}{l}\text { Settlement farm } \\
\text { DI 1:471. Part of Reykholt estate. }\end{array}$ \\
\hline 15 & Reykholt & $\begin{array}{l}\text { Landnáma } \\
\text { List of priests } \\
\text { charter } \\
\text { List of churches } \\
\text { Sturlunga saga }\end{array}$ & $\begin{array}{l}12 \text { th } \\
1143 \\
1180 \mathrm{~s} \\
\text { c. } 1200 \\
13 \text { th }\end{array}$ & Parish church & $\begin{array}{l}\text { Archaeological date: } 10 \text { th-12th century. } \\
\text { DI 1:188-89. Páll Sölvason lived at Reykholt. } \\
\text { DI 1: 279-280. } \\
\text { DI 12:10. }\end{array}$ \\
\hline $\begin{array}{r}8 \\
31 \\
30 \\
16\end{array}$ & $\begin{array}{l}\text { Hægindi } \\
\text { Norðurreykir } \\
\text { Háfur } \\
\text { Grímsstaðir }\end{array}$ & $\begin{array}{l}\text { Charter } \\
\text { Charter } \\
\text { Charter } \\
\text { Sturlunga saga } \\
\text { Charter }\end{array}$ & $\begin{array}{l}1206 \\
1206 \\
1206 \\
13 \text { th } \\
1463\end{array}$ & & $\begin{array}{l}\text { DI 1:471. Part of Reykholt estate. } \\
\text { DI 1:471. Part of Reykholt estate. } \\
\text { DI 1:471. Part of Reykholt estate. } \\
\text { Owned by Reykholt }\end{array}$ \\
\hline 18 & Skáney & $\begin{array}{l}\text { Landnáma } \\
\text { Charter }\end{array}$ & $\begin{array}{l}12 \text { th } \\
1367\end{array}$ & Annex church & $\begin{array}{l}\text { 11th century brooch found in home field. } \\
\text { DI 3:222. Human bones found in home field. } \\
\text { Dórðarson 1936:44-45. }\end{array}$ \\
\hline 21 & $\begin{array}{l}\text { Sturlureykir/ } \\
\text { Gullsmiðsreykir }\end{array}$ & Deed & 1463 & Annex church & DI 5:400. \\
\hline 28 & Hurðarbak & Sturlunga saga & 13th & & \\
\hline 23 & Deildartunga & Deed & 1178 & Annex church & $\begin{array}{l}\text { DI 1:189. } \\
\text { Priest living at farm. Vésteinsson 2000b:98. }\end{array}$ \\
\hline 32 & Signýjarstaðir & Landnáma & 12th & & \\
\hline $\begin{array}{l}34 \\
33\end{array}$ & $\begin{array}{l}\text { Refsstaðir } \\
\text { Bolastaðir }\end{array}$ & $\begin{array}{l}\text { Charter } \\
\text { Charter }\end{array}$ & $\begin{array}{l}1258 \\
1590\end{array}$ & & $\begin{array}{l}\text { DI 1:593-4. } \\
\text { AI II:204. Lay abandoned in } 1590 .\end{array}$ \\
\hline 35 & Sigmundarstaðir & Landnáma & 12th & & \\
\hline $\begin{array}{l}36 \\
37\end{array}$ & $\begin{array}{l}\text { Kolslækur/ } \\
\text { Hálsar }\end{array}$ & $\begin{array}{l}\text { Landnáma } \\
\text { Heiðarvíga saga }\end{array}$ & $\begin{array}{l}\text { 12th } \\
12 \text { th }\end{array}$ & & Archaeological dates: mid-10th-late 13th century. \\
\hline 38 & Uppsalir & Deed & 1563 & & DI 15:157. \\
\hline 39 & Hofstaðir & Landnáma & 12th & & \\
\hline 40 & Úlfstaðir & Landnáma & 12th & & \\
\hline $\begin{array}{l}42 \\
43 \\
\end{array}$ & $\begin{array}{l}\text { Rauðsgil } \\
\text { Búrfell } \\
\end{array}$ & $\begin{array}{l}\text { Landnáma } \\
\text { Deed }\end{array}$ & $\begin{array}{l}12 \text { th } \\
1563\end{array}$ & & $\begin{array}{l}\text { Settlement farm. } \\
\text { DI } 15: 157 .\end{array}$ \\
\hline 44 & Auðsstaðir & Landnáma & 12th & & \\
\hline 47 & Stóri Ás & $\begin{array}{l}\text { Landnáma } \\
\text { Charter }\end{array}$ & $\begin{array}{l}12 \text { th } \\
1258\end{array}$ & Parish church & $\begin{array}{l}\text { Settlement farm. } \\
\text { DI } 1: 593-4 .\end{array}$ \\
\hline 49 & Vatnskot & Charter & 1258 & & DI 1:593-4. Abandoned in 13th century. \\
\hline 45 & Giljar & Charter & 1258 & & DI $1: 593-4$ \\
\hline 46 & Augastaðir & Charter & 1258 & & DI 1:593-4. \\
\hline 48 & Hraunsás & $\begin{array}{l}\text { Landnáma } \\
\text { Charter }\end{array}$ & $\begin{array}{l}12 \text { th } \\
1463\end{array}$ & & DI 5:399-400. Half owned by Reykholt. \\
\hline
\end{tabular}


probably largely as a result of over-exploitation of the woodland.

It is clear from the above survey that the available sources cannot give an accurate picture of land division in the study area at the time of settlement. Human activity has only been archaeologically dated at two sites, Reykholt and Háls, to c. A.D. 1000 and the late 9th centuries, respectively. The earliest references to the other farms marked on the map in Figure 2 are of 12th- and 13th-century dates and later, which is, therefore, the true time period reflected in the topographical analysis presented below. This settlement division is likely to go back to earlier times, although this cannot be proven.

On the above basis, 16 land holdings are identified in the study area (Fig. 2) that can be considered as having been settled during the first centuries of farm establishment. Some of these holdings contained more than one farm from early on (Table 1). Several dependent farms are mentioned in sources from the Later Medieval/Early Modern Period as having been established on the larger holdings, some of which were only occupied for a short period of time. The earliest reference to most of these is in an early 18th-century land survey (Jarðabók 1925 and 1927), although some may well be earlier.

The boundaries for the different land holdings used in this study and illustrated in Figure 2, are the ones used in Vésteinsson et al. (2002). They are largely based on the 19th/early 20th century Landamerkjabók, which is a collection of boundary documents of individual holdings compiled for the sheriff of the area and still serves as the basis for present property divisions. Other sources that can throw light on earlier boundary lines are the previously mentioned Landnámabók, which gives some landmarks, medieval documents published in the Diplomatarium Islandicum (DI) series, and cartographic and ethnographic sources. Some of the boundary-lines are more permanent than others and therefore likely to have been in place unchanged through the centuries, such as gorges, large boulders used to define line-of-sight limits, and the river course at the valley bottom, although this has clearly shifted somewhat through the centuries; others are less permanent and therefore less reliable, such as cairns and earthworks. Historically, the main settlements seem to have been stable through the centuries. On that basis and with due reservations, these predominantly recent boundary lines are used retrospectively to reflect much earlier times.

The numbers in Figure 2 are the same as those in Table 1, referring to the farmsteads on each holding thought to have been occupied in the first centuries of settlement. In the table, they are grouped accordingly.

\section{Archaeological and Palaeoecological Data}

Archaeological survey has been carried out in most of the study area (Pétursdóttir 2002; Vésteinsson 1996, 2000a). A result that is of particular importance for this discussion is the apparent stability of the farmhouse locations until very recent times. In most cases, the present dwelling house has been built on top of the old farm-mound, inevitably causing severe damage to any older remains. At about a third of the sites, the dwelling has been moved down slope, to the valley bottom, but this only happened around the middle of the last century. It was also at that time when tremendous changes took place in farming methods that until then seem to have been to a large extent unchanged since the beginning of settlement. Machines were for the first time used to dig drainage ditches, and large areas were turned into fields, mostly for the cultivation of grass used to feed the domestic animals on which the Icelandic farming economy has always been based. Prior to this expansion in activity, only a small area around the farm had been levelled by hand and cultivated, creating the infield, which was usually surrounded by an enclosure. These old infield areas at individual farms were planned in the first quarter of the 20th century, and the plans (túnakort) are kept in the National Archives of Iceland in Reykjavík. The fact that there was little change in farm locations and the size of cultivated areas until after the middle of the 20th century suggests that these plans give a good picture of what the individual farms may have been like physically in much earlier times.

Palaeoecological analysis was a part of the archaeological excavations at Reykholt (Sveinbjarnardóttir et al. 2007), and such investigations have also been carried out in the vicinity of the site (Gathorne-Hardy et al., in prep.). Pollen, insect, and plant macro-analyses indicate that the main environmental change in the valley after settlement was in the woodland that covered the area, particularly the higher slopes. Although there was a decline in the woodland immediately after the initial settlement period, as indicated by the landnám tephra layer (dated to $871 \pm 2$ AD; Grönvold et al. 1995), it was first drastically reduced between c. A.D. 1150 and 1300. Today the area is devoid of trees. Soils-based evidence suggests an increase in soil wetness associated with this phase of vegetation cover change (I. Simpson, unpubl. data). Some cereal was grown locally during the initial period of habitation, but by the 13th century there is no evidence of this in the pollen record (Erlendsson 2007). These findings are supported by the written sources which mention cereal cultivation at the site in the 1180s and 1224 charters (DI 1, 280, 471), but not in the 1358 charter (DI 3, 122-3). Neither shift seems to have been linked to climatic deterioration, since climate 
appears to have been fairly stable until c. 1400, when temperatures were brought down by c. $1{ }^{\circ} \mathrm{C}$ (Gathorne-Hardy et al., in prep.). Rather, these changes appear to have been the result of, on the one hand, over-exploitation of the woodland and on the other, a management decision on cereal cultivation. A reduction in the availability of wood as fuel led to an increase in the use of peat and animal dung. This shift may have had the result that less dung was available as manure, resulting in lowered soil fertility.

Soils reflect the environment in which they have been formed. By using techniques such as thin section micromorphology of undisturbed soil samples and total phosphorus analyses of bulk samples, interpretations about their management and historic environments can be made. Such analyses have been undertaken on soil samples from the home fields at Breiðabólstaður, Grímsstaðir, and Reykholt, all contained within the boundaries of the Reykholt estate by the 15 th century (I. Simpson, unpubl. data). In thin section, evidence of cultural amendment of the soil is expressed in traces of micron-scale bone fragments, peat ash residues, fine charcoals, and cut marks attributable to cultivation. Evidence for amendment is, however, slight, and consists of domestic debris rather than the waste turfs and manures that are more normally found where manuring of land is a major land management strategy in the Norse North Atlantic region (Simpson 1997). The identification of animal manures and a range of fuel wastes in the midden at Reykholt suggests that material that could have been applied to the home field was instead deposited as part of the midden close to the farm houses (Sveinbjarnardóttir et al. 2007). Total phosphorus levels are low (ranging from 135-220 mg/100 g), again suggesting limited soil amendment.

These observations suggest that in all the home fields associated with the Reykholt estate, little effort was made to maintain or enhance home-field soil fertility. Cereal production was unlikely to be a major aspect of land management in the home field, with inherent land fertility or importing of hay from meadows relied on for winter fodder. This soilsbased evidence from Reykholt is in marked contrast with that from the ecclesiastical power center of the Bishop's seat at Skálholt, where there is evidence of heavy amendment of the home field from its earliest phases of formation (I. Simpson, unpubl. data). This comparison opens up the possibility of contrasting land management strategies between different power centers.

At Háls, further up the valley, palaeoecological investigations undertaken in the home field showed that the area, now completely devoid of trees, was covered with birchwood before the site became an iron-extraction site in the late 9th and 10th centuries. Logs of fully grown trees were found in deposits pre- dating the landnám tephra layer, coupled with high levels of birch pollen, which dropped dramatically shortly after iron production began (Dixon 1997, Smith 2005). These changes, as at Reykholt, were associated with increases in soil wetness (I. Simpson, unpubl. data).

\section{Topographical analyses}

The three categories of early settlement recognized in Reykholtsdalur and described above have, were termed by Vésteinsson et al. (2002) as "large complex settlements," "large simple settlements," and "planned settlements." A large complex settlement is characterized by access to a wide range of resources and by having a number of households in residence. It was usually a political center, with a parish church associated with it. Reykholt (15) fits this category, as does Stóri Ás (47), just east of the study area and belonging to another initial landtake. Large simple settlements are characterized as having a somewhat more limited and less-varied resource base. They supported fewer households than did large complex settlements, and usually had a chapel or an annex church. Skáney (18), Sturlureykir (21), Deildartunga (23), and Steindórsstaðir (10), which lies just outside the study area, fall into this settlement category. In contrast, planned settlements are characterized as occupying a small area, and as a rule, supporting only a single household (Tables 1 and 2). This classification formed the basis for the GIS-based topographical approach used to define key bio-physical attributes of land associated with the Reykholtsdalur settlements. These attributes include elevation, aspect, slope, annual insolation, summer insolation, and extent of marshy areas; ${ }^{5}$ size of land holdings and farm locations are also included in the analyses. The land attributes selected are not readily modified by human activity, carry increased significance in view of the absence

Table 2. Settlement classes within the Reykholtsdalur area.

\begin{tabular}{lcl} 
Name & Area (ha) & Settlement class \\
\hline Refsstaðir & 668 & Planned \\
Hamrar & 425 & Planned \\
Sturlureykir & 1280 & Large, simple \\
Hofsstaðir & 434 & Planned \\
Kolslækur & 246 & Planned \\
Kjalvararstaðir & 396 & Planned \\
Kleppjárnsreykir & 203 & Planned \\
Kópareykir & 454 & Planned \\
Reykholt & 2036 & Large, complex \\
Sigmundarstaðir & 365 & Planned \\
Signýjarstaðir & 780 & Planned \\
Skáney & 935 & Large, simple \\
Snældubeinsstaðir & 421 & Planned \\
Deildartunga & 1068 & Large, simple \\
Ulfsstaðir & 383 & Planned \\
Uppsalir & 468 & Planned \\
\hline
\end{tabular}


of substantial evidence for land improvement, and act as proxy indicators for a range of related land attributes including seasonal and spatial patterns of vegetation productivity and diversity.

\section{Capture and projection of geographic data sets}

The study area is covered by the 1:50,000 maps 5520 I (Lundur) and 5521 II (Northtunga) (Series C762, 1948, American Army Map Service). The map sheets from 1948 were based on the Universal Transverse Mercator grid (Zone 27), International 1909 spheroid, with a horizontal datum based on the Astronomic Station at Reykjavík (2155'51.15"W, $\left.64^{\circ} 08^{\prime} 31.88^{\prime \prime N}\right)$, which is no longer used. The transformation to the Lambert/WGS84 projection was carried out using information from the Land Survey of Iceland website (http://www.lmi.is/landsurvey.nsf/ htmlPages/goproweb0190.html). This transformation is a "best-fit" and does not give geodetic accuracy. The eastern tip of the research area is covered by map sheet 1714 III (Series C761, Defense Mapping Agency, 1977-1990). Settlement boundaries are taken from the webpage of Nytjaland (http:/eldur.lbhi.is/ website/nytjaland/viewer/htm) compiled by the Agricultural University of Iceland, adapted on the basis of the boundary sources mentioned earlier and overlain on a 1913 map at 1:50,000 scale. Maps were scanned and geo-referenced in Erdas Imagine 8.5, ${ }^{6}$ and settlement boundaries, farm locations and marsh areas were digitized from the scanned maps in ARC/INFO. ${ }^{7}$ The resultant data sets were then transformed in ARC/ INFO, so that their projection and datum matched that of the digital terrain model (Table 3). Elevation information for the area was supplied by a digital terrain model based on 90-m grid cells (equivalent to 1 : 50,000 scale). Slope and aspect topographic information has been derived from this data set; the area and proportional coverage of each elevation, slope, and aspect class within individual settlement areas was calculated from it as well.

\section{GIS-based topographies}

The Reykholtsdalur area has fairly gentle, lowlying topography, and most of the settlement areas lie below $150 \mathrm{~m}$ a.s.l. Slopes are relatively gradual,

Table 3. Projection information for geographic data sets.

\begin{tabular}{lc} 
Projection & Lambert \\
\hline Datum & WGS84 \\
Spheroid & WGS84 \\
Units & Metres \\
1st standard parallel & $64^{\circ} 15^{\prime} 0.000^{\prime \prime}$ \\
2nd standard parallel & $65^{\circ} 45^{\prime} 0.000^{\prime \prime}$ \\
Central meridian & $-19^{\circ} 00^{\prime} 0.000^{\prime \prime}$ \\
Latitude of origin & $65^{\circ} 00^{\prime} 0.000^{\prime \prime}$ \\
False easting & 500000 \\
False northing & 500000 \\
\hline
\end{tabular}

being mostly $<10^{\circ}$. The east-west orientation of the region's topography means that the greatest area of land is either north or south facing; a very small proportion of the area is totally flat (Fig. 3). Figure 4 shows the relative spatial variation in annual and summer insolation (the amount of solar radiation received at the earth's surface, although these values may be greatly modified by cloud cover and atmospheric water content) for the region. The relatively gentle slopes mean that there are subtle but not huge variations in insolation across the area. Most of the region receives between 3000 and $4000 \mathrm{MJ} \mathrm{m}^{-2}$ annually, and the bulk of this insolation is received in the summer months (May-September), when most areas receive between 2700 and $3300 \mathrm{MJ} \mathrm{m}^{-2}$. The area of marshy land was digitized from the 1948 topographic maps, before large-scale drainage had taken place in the region and indicates an area of c. 5203 ha. Figure 2 shows that there were considerable areas of marshy land on all the holdings in the study area, covering at least 25\% of the settlement area, and up to $87 \%$ in one case (Table 4).

The Reykholt estate, characterized as a "large complex settlement," displays a wide topographic range within its boundaries. Elevation classes range from c. 50-350 m, with the lower elevation ranges dominant. Similarly, a range of slope classes are also evident $\left(0-\right.$ c. $\left.25^{\circ}\right)$, with much of the area in the range of $0-5^{\circ}$. Both north and south aspect classes are dominant within the estate, since it stretches across the whole valley and over the hill down to the Hvítá River on the north side, but all aspect categories are represented (Figs. 5, 6, and 7c). Annual insolation also has a considerable range, reflecting aspect and slope, from c. 2000-4500 $\mathrm{MJ} \mathrm{m}^{-2}$, with much of the insolation in the 3500-4000 $\mathrm{MJ} \mathrm{m}^{-2}$ category. Summer insolation reflects the wide an-

Table 4. Area and proportion of marshland on each settlement.

\begin{tabular}{lcc} 
Settlement & $\begin{array}{c}\text { Area of } \\
\text { marsh (ha) }\end{array}$ & $\begin{array}{c}\text { \% of farm area } \\
\text { that is marsh }\end{array}$ \\
\hline Refsstaðir & 422.1 & 63 \\
Hamrar & 186.2 & 44 \\
Sturlureykir & 571.6 & 45 \\
Hofsstaðir & 271.8 & 63 \\
Kolslækur & 179.7 & 73 \\
Kjalvararstaðir & 98.4 & 25 \\
Kleppjárnsreykir & 67.3 & 33 \\
Kópareykir & 114.3 & 25 \\
Reykholt & 970.9 & 48 \\
Sigmundarstaðir & 241.0 & 66 \\
Signýjarstaðir & 240.8 & 31 \\
Skáney & 409.8 & 44 \\
Snældubeinsstaðir & 141.0 & 34 \\
Deildartunga & 933.9 & 87 \\
Ulfsstaðir & 94.8 & 25 \\
Uppsalir & 259.1 & 55 \\
\hline
\end{tabular}


nual range with $\mathrm{MJ} \mathrm{m}^{-2}$ values from c. 2100-3300 (Figs. 8 and 9). While the Reykholt estate has the largest area of marshland, an important type of land for collecting animal fodder, this type only made up approximately $48 \%$ of the estate's total land area (Table 4). Reykholt has also, through the centuries, accommodated the greatest number of farm sites within its boundaries (Table 1). By the 15th century, it is the largest land holding in the study area and is nearly twice the size of the next largest, Sturlureykir, classed as a "large simple settlement," and ten times the size of the smallest settlement, Kleppjárnsreykir, classed as a "planned settlement."

Three settlements within the study area, Sturlureykir, Skáney, and Deildartunga, are considered to fall into the "large simple settlement" category, with a size range of 935-1280 ha. These settlements also accommodated additional farms at different times.

\begin{tabular}{|c|c|c|}
\hline 1. Deildartunga & 7. Sigmundarstað̃ir & 13. Ulfsstađ̃ir \\
\hline 2. Sturlureykir & 8. Hamrar & 14. Hofsstaðir \\
\hline 3. Skáney & 9. Kleppjárnsreykir & 15. Uppsalir \\
\hline 4. Reykholt & 10. Snældubeinnstað̋ir & 16. Kolslækur \\
\hline 5. Signýarstađ̋ir & 11. Kjalvarastaðir & \\
\hline 6. Refsstað̃ir & 12. Kópareykir & \\
\hline
\end{tabular}

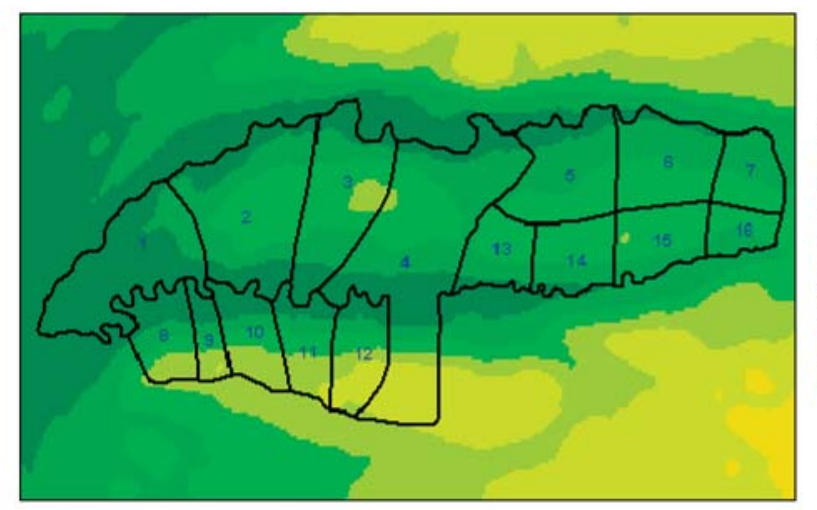

\section{ELEVATION}

Estate boundaries

Digital terrain model $(\mathrm{m})$

Sea level

$<50 \mathrm{~m}$

$50-100 \mathrm{~m}$

$100-200 \mathrm{~m}$

$200-300 m$

$300-400 \mathrm{~m}$

$400-500 m$

$500-600 m$

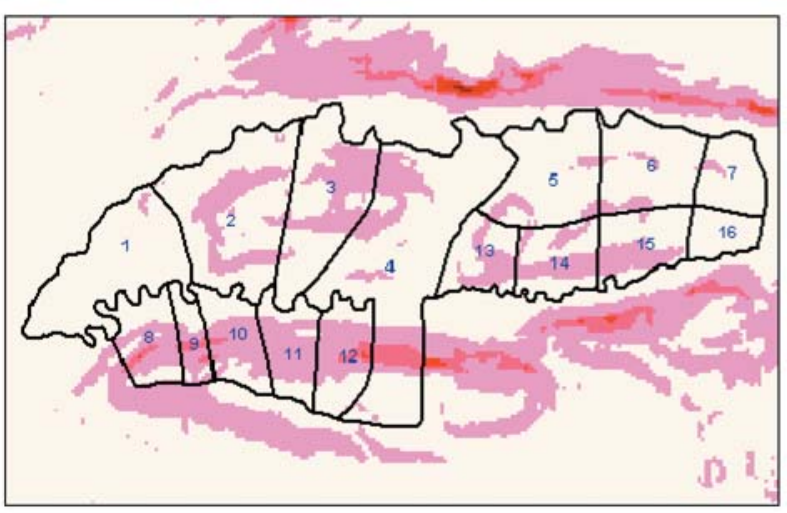

SLOPE
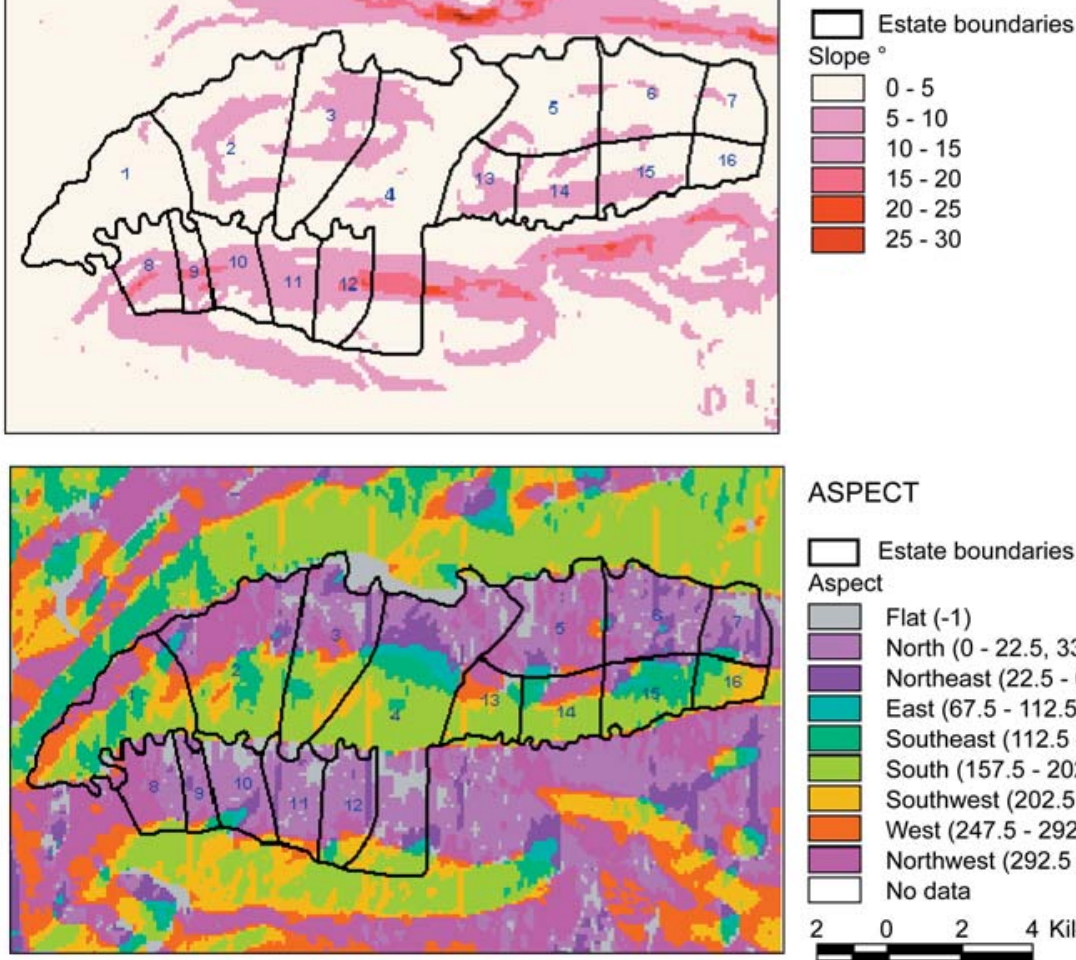

ASPECT

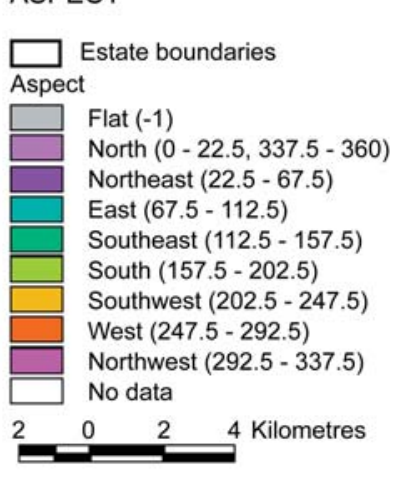

Figure 3. GIS-based topographical analyses of elevation, slope, and aspect, Reykholtsdalur, Iceland.
The topographic range of these holdings is more restricted in comparison with the "large complex settlement;" elevation range on these three holdings is from c. 50 to c. $250 \mathrm{~m}$, with slope classes ranging from 0 to c. $15^{\circ}$ and with aspects that are predominantly north, northwest, and south (Figs. 5, 6, and 7c). Annual insolation ranges are similarly restricted, although much of the insolation, as at Reykholt, is in the $3500-4000 \mathrm{MJ}$ $\mathrm{m}^{-2}$ category; similarly, the summer insolation range is restricted to the 2700-3000 and 3000-3300 $\mathrm{MJ} \mathrm{m}^{-2}$ categories (Figs. 8 and 9). Sturlureykir (45\%) and Skáney (44\%) have similar percentage areas of marshland within the settlement boundary, in marked contrast to Deildartunga, which has approximately $87 \%$ of its areas as marshland, considerably more than that of Reykholt (Table 4). Deildartungaisalsomarked by its topographical simplicity, with the least topographic range of any of the settlements within the study area.

The twelve smaller settlements within the study area, specified as "planned settlements," are characterized by a 
size range that varies from 203-780 ha and typically have only a single farm on their land. Based on size and topographic data, these settlements can be divided into two categories. The first of these categories is confined to the five settlements in the south and west, which are among the smallest in the study area (203454 ha), but have a wider topographic range than the other "planned settlements" (Fig. 3, Table 2). These elements typically include a full range of elevation classes, from c. 50-c. $350 \mathrm{~m}$, and, with the exception of is typically in the $3500-4000 \mathrm{MJ} \mathrm{m}^{-2}$ class, although it can range from 3000-5000 $\mathrm{MJ} \mathrm{m}^{-2}$; summer insolation is typically 2700-3000 $\mathrm{MJ} \mathrm{m}^{-2}$ (Figs. 8 and 9). Marshland varies from 25-73\% of settlement area (Table 4).

\section{Discussion}

The study area, a valley rising inland, c. 25 km away from the sea, constitutes a typical Icelandic valley well suited for farming. It is flanked by a series
Kjalvararstaðir, slope class ranges from 0-c. $20^{\circ}$ and are predominantly northerly and northwesterly in aspect (Figs. 5, 6, and 7a). Annual insolation ranges are typically c. 2500-c. $4500 \mathrm{MJ} \mathrm{m}^{-2}$, but are predominantly in the 3000-4000 MJ $\mathrm{m}^{-2}$ range; the summer insolation range is in the 2700-3000 $\mathrm{MJ} \mathrm{m}^{-2}$ category (Figs. 8 and 9). Marshland covers between 25 and $44 \%$ of these settlement areas (Table 4). The second of the "planned settlement" categories is found within the north and east part of the study area (Fig. 2, Table 2). These sites are generally larger in size (246-780 ha) than the first category of "planned settlements," but with less topographic diversity. Here, elevation classes range from c. 50-250 m. Although more restricted at Kolslækur and Sigmundarstaðir, slope class ranges are typically from $0-10^{\circ}$ with predominantly north and northwest aspects and more limited south and southeast aspects (Figs. 5, 6, and 7b). Annual insolation

\begin{tabular}{|c|c|c|}
\hline 1. Deildartunga & 7. Sigmundarstaôir & 13. Ulfsstađ̋ir \\
\hline 2. Sturlureykir & 8. Hamrar & 14. Hofsstað̄ir \\
\hline 3. Skáney & 9. Kleppjárnsreykir & 15. Uppsalir \\
\hline 4. Reykholt & 10. Snældubeinnstað̌ir & 16. Kolslækur \\
\hline 5. Signýarstað̋ir & 11. Kjalvarastað̋ir & \\
\hline 6. Refsstað̋ir & 12. Kópareykir & \\
\hline
\end{tabular}
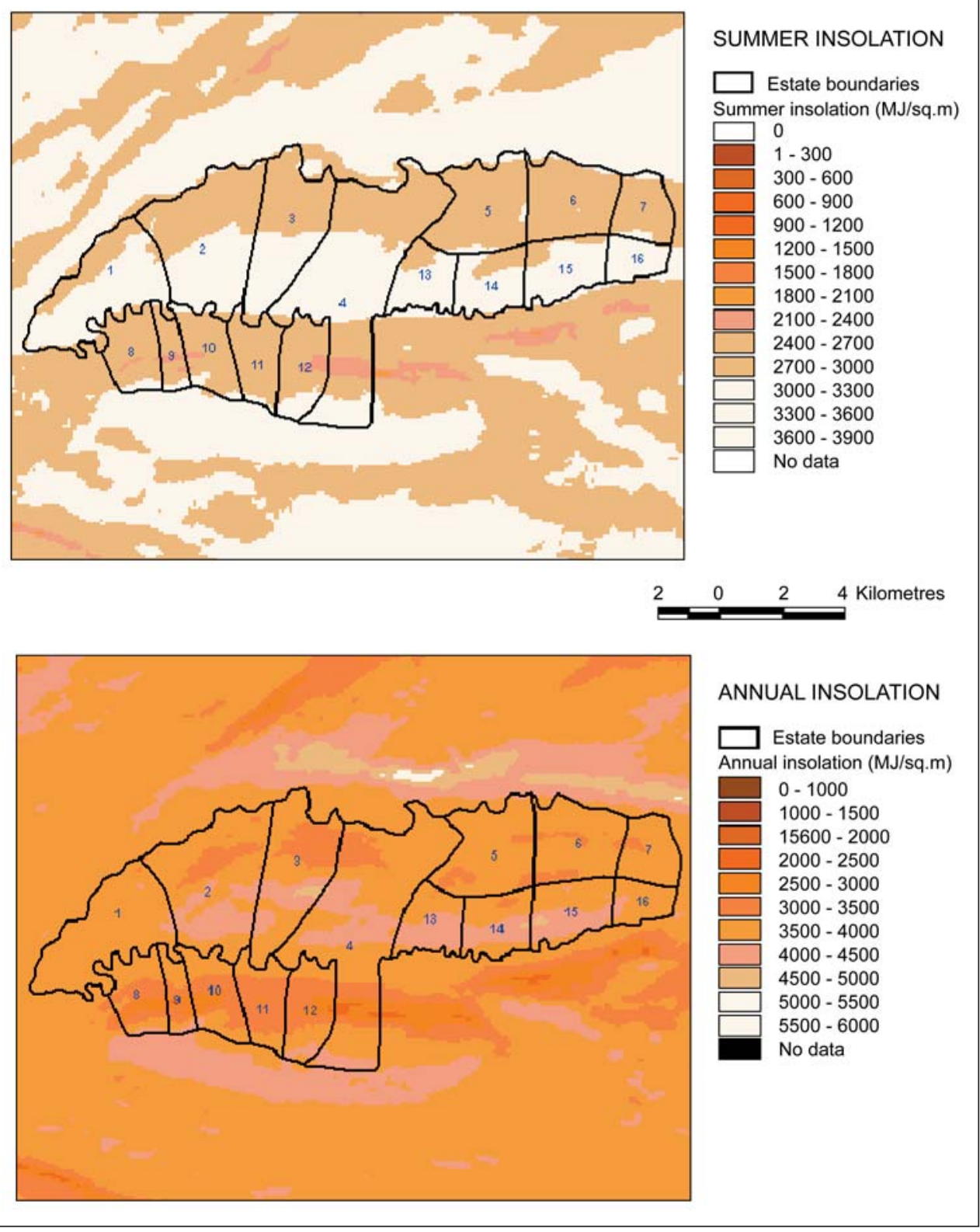

Figure 4: GIS-based summer and annual insolation, Reykholtsdalur, Iceland. 


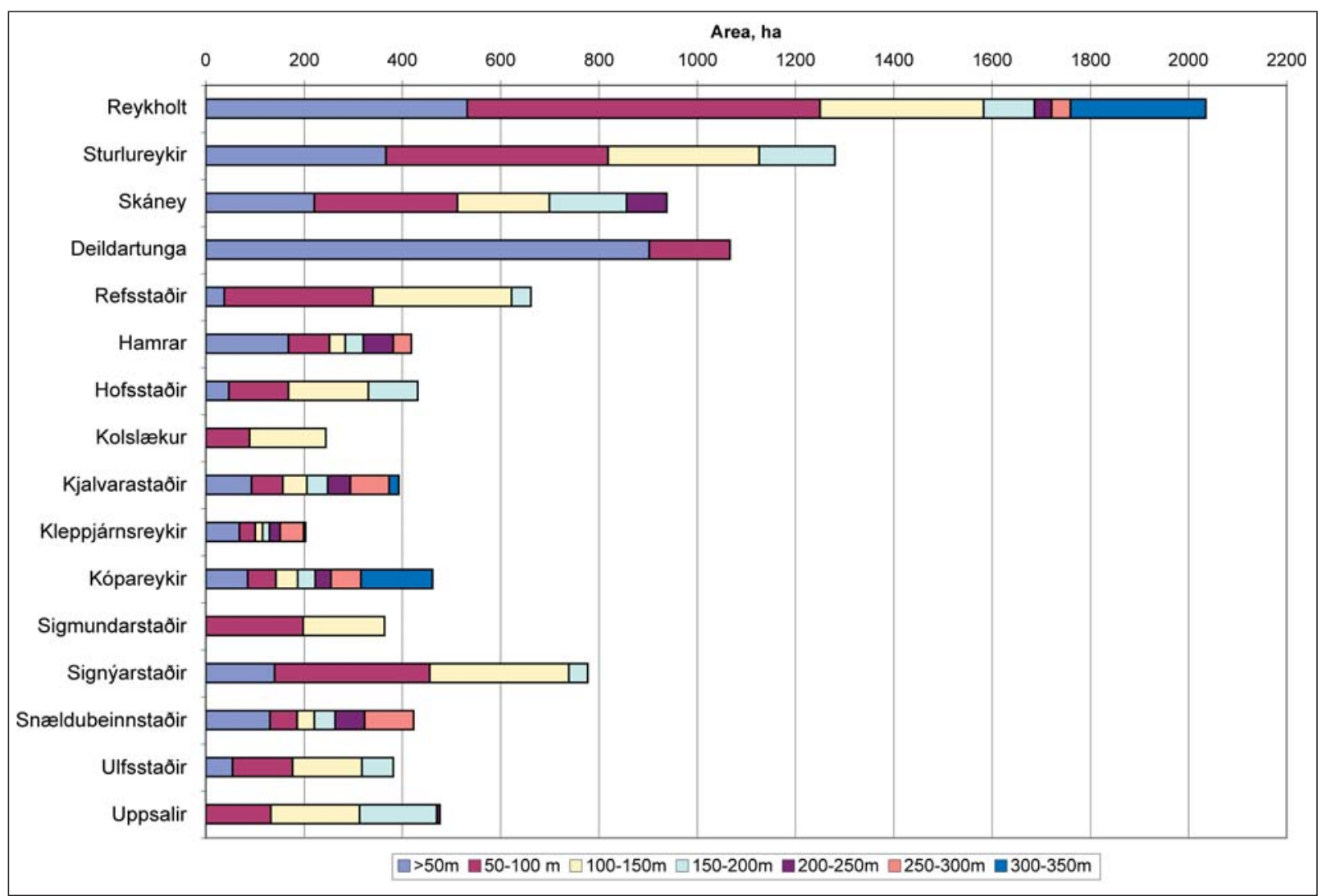

Figure 5. Area of settlement within each elevation class. The bar chart represents elevation classes in meters (m).

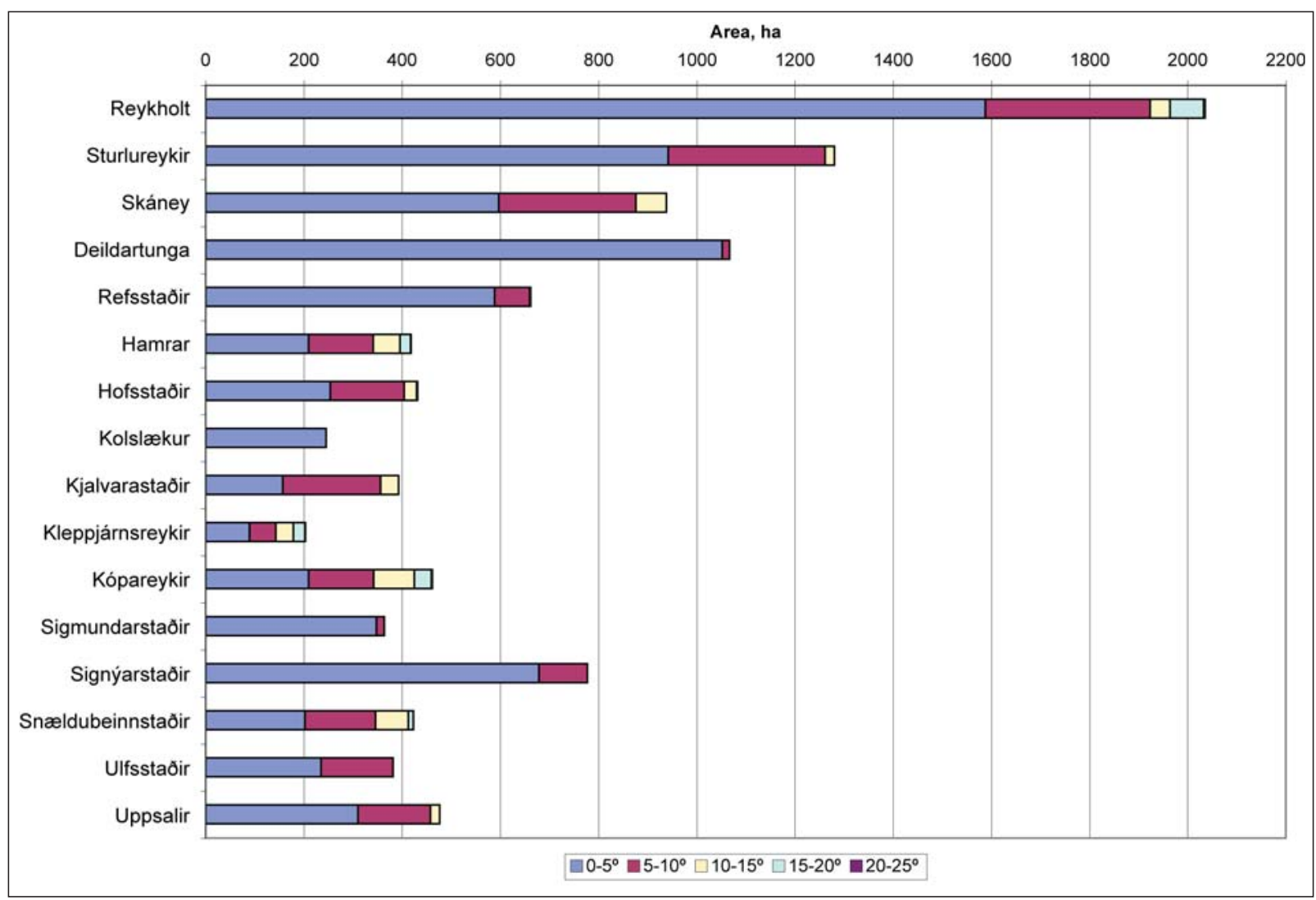

Figure 6. Area of settlement within each slope class. The bar chart represents slope classes in degrees $\left({ }^{\circ}\right)$. 

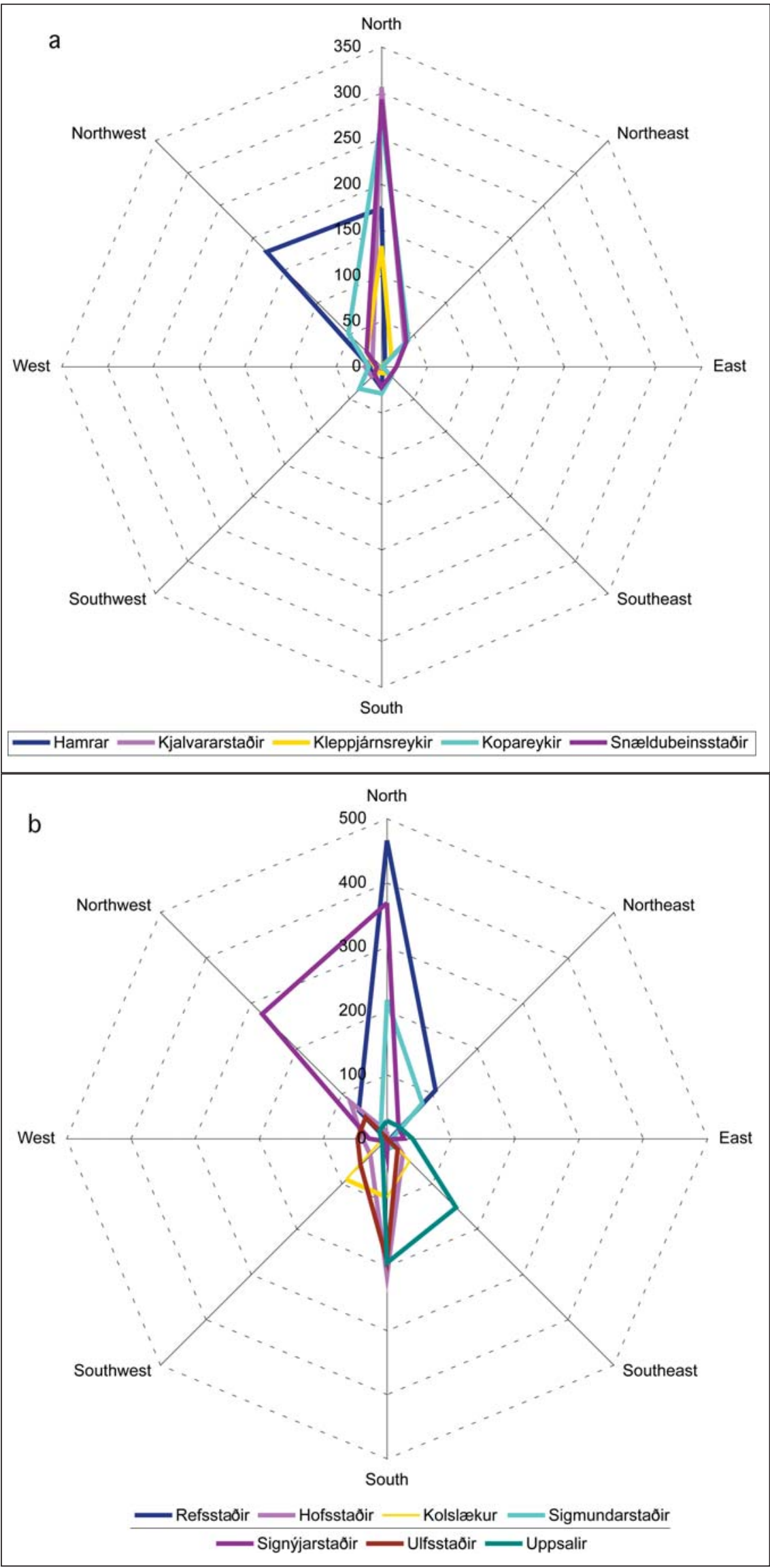

Figure 7. Areas within each aspect class: a) planned settlement, west, and b) planned settlement, east. See next page for: c) large simple and large complex settlements. of long, gently sloping hills, averaging about 270 m.a.s.l. in height, with the most fertile land lying closest to the river. The valley opens out to the west, where the most extensive lowland area is, with soils becoming thinner and less productive further inland. The area, including the Reykholt estate, enjoys the additional bonus of a number of hot and warm springs that were used by the inhabitants from early on (Sveinbjarnardóttir 2005a). Growing conditions will certainly have been enhanced in the springs' vicinity. On the whole, but in particular in the lower half of the valley, a good range of land resources for domestic livestock production was available and a basis for the local economy.

Although the details of the earliest settlement process cannot be precisely dated, the topographic analyses suggests that during the partitioning of Reykholtsdalur, land resources were important in the process, with the better quality land being allocated to the largest settlements Skáney (18), Sturlureykir (21), and Deildartunga (23) lower down the valley. The Reykholt estate, which had taken over what is thought to have been the initial settlement farm, Breiðabólstaður (13), by c. 1200 , is associated with a wide topographic range indicative of the widest range of land resources in the area, comparable to that belonging to the initial occupant at Breiðabólstaður. Crucially, though, Reykholt gradually acquired more land nearby and had the use of woodland areas and extensive mountain pastures some distance away from the home farm. These pastures, accessed during the summer months, ensured a resilient economy 


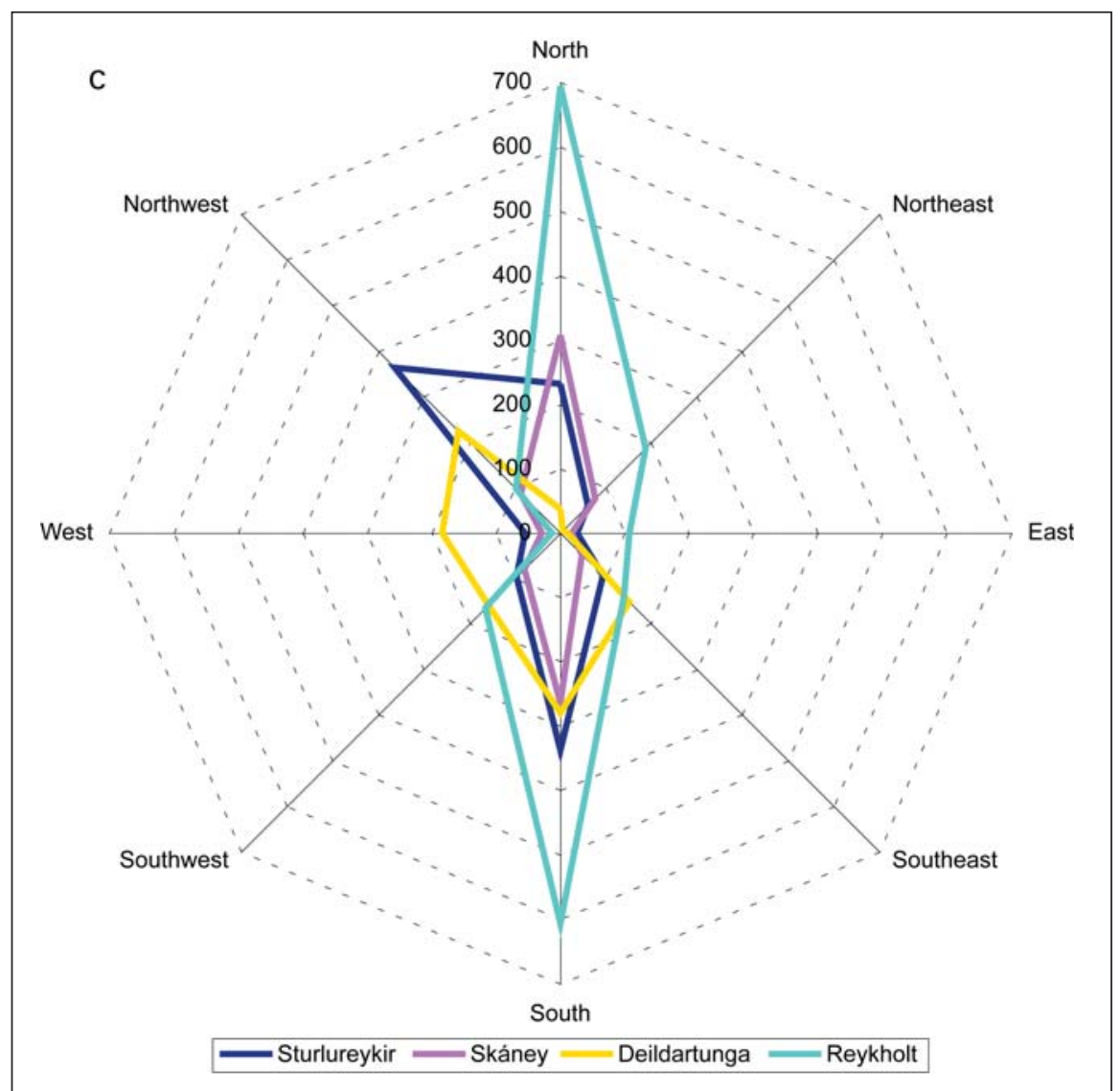

Figure 7c. Areas within each aspect class: large simple and large complex settlements. based on a diverse land resource base, and were vital for the emergence of Reykholt as a center of power (Eypórsson 2007). It is significant that it is the accumulation of land area rather than the intensification of land use that contributes to this process.

The three "large simple settlements" created as part of the partitioning of Reykholtsdalur, although somewhat smaller than the Reykholt estate and with less topographical range, did contain considerable areas of marshland on river banks in the valley bottom, particularly towards the lower, more fertile end of the valley. These were the best areas for winter fodder collection, always an important part of Icelandic farming. Winter fodder was particularly important for

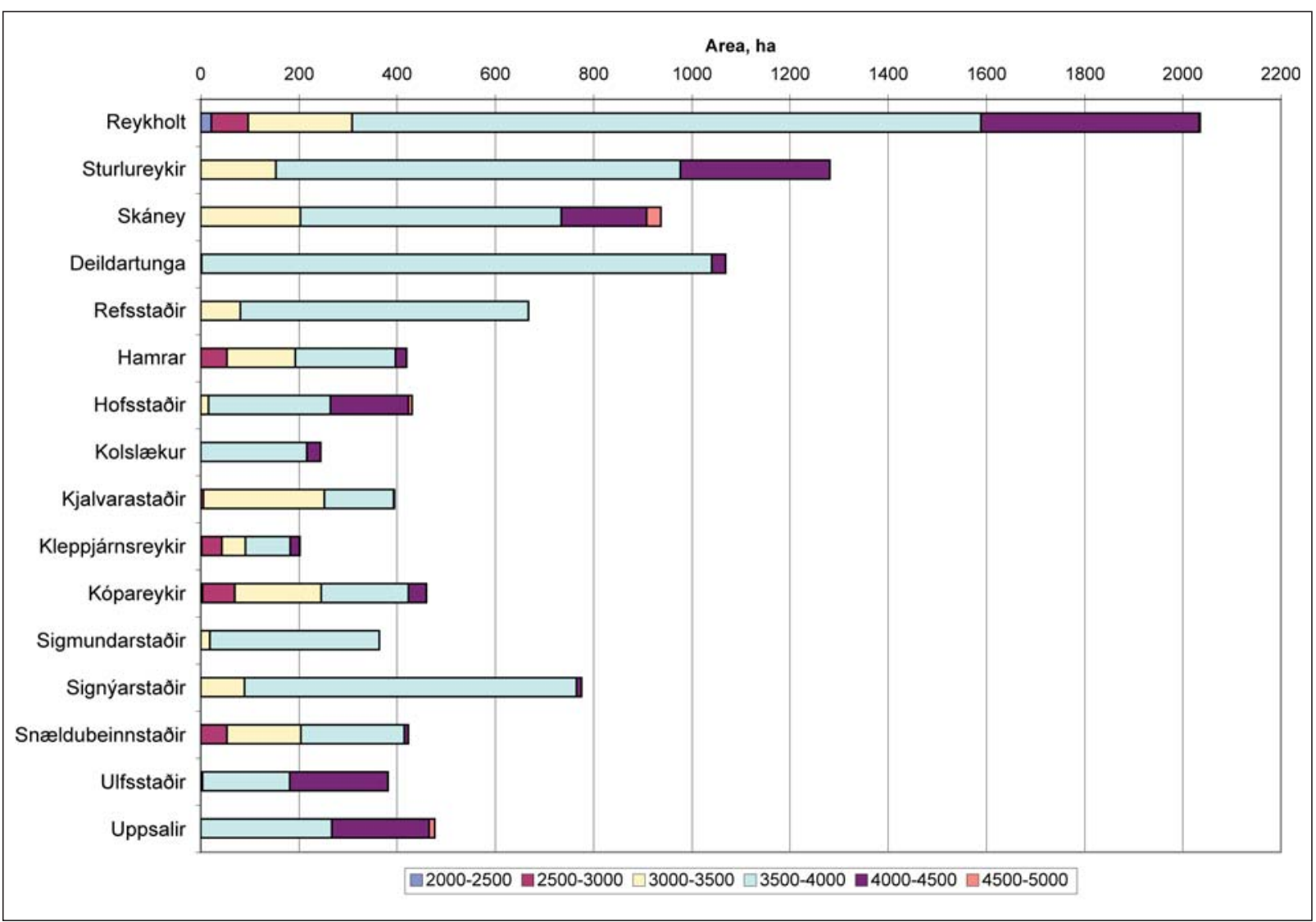

Figure 8. Area of settlement within each annual insolation class. The bar chart represents insolation class in $\mathrm{MJ}^{-2}$. 
cattle, on which there was more emphasis than sheep during the initial period of settlement and which could not be grazed in the winter. These settlements also enjoy the extensive summer insolation, making growing conditions quite favourable. These results might suggest that while the Reykholt estate retained the broadest land resource base, the three next largest settlements were no less prosperous, focussing on requirements for livestock production.

The "planned settlements" are smallest in size of the land partition categories considered, with the smallest, predominantly north-facing farms on the south side of the river having a broader range of topography to draw on than the larger farms on the north side of the river. These north-side farms enjoyed a southerly exposure and a higher annual insolation. Some of them had more than one farm, whereas none of the ones on the south side of the river did (Table 1). The broader topographical range on the south side of the river may have been a compensation for the holdings being smaller in area and having a northerly direction. In addition, access to the most fertile farming land towards the lower end of the valley bottom, and the presence of hot and warm springs enhancing growing conditions, made these settlements highly viable. The desirability of this land is, perhaps, demonstrated by the fact that several of these settlements were acquired by and enriched the Reykholt estate (see Table 2).
The topographical analysis indicates that the inherent quality of land played a large role in the way the initial large land-take, bordered by the two rivers in the Reykholtsdalur valley, was partitioned. The historical and archaeological evidence for Reykholt, the central settlement in the valley, indicates that the farm, which seems to have been established by c. A.D. 1000 on the land of the initial settlement in the valley, was a major farm from the outset, taking over the land and leading role of the initial farm and including several other farmsteads within its holding. While the quality of the land belonging to the estate is somewhat inferior for livestock production to that of the three "large simple settlements" occupying the prime land to the south of it, the estate made up for this shortcoming and got steadily wealthier through the acquisition of various land resources in and outside the valley.

\section{Conclusion}

Analyses of historical and topographical information from Reykholtsdalur, with supporting information from archaeological and environmental data, suggest that inherent land attributes played a significant role in the way the landscape was carved up during the period of initial settlement and colonization of Iceland. The earliest available sources post-date the settlement period, but they

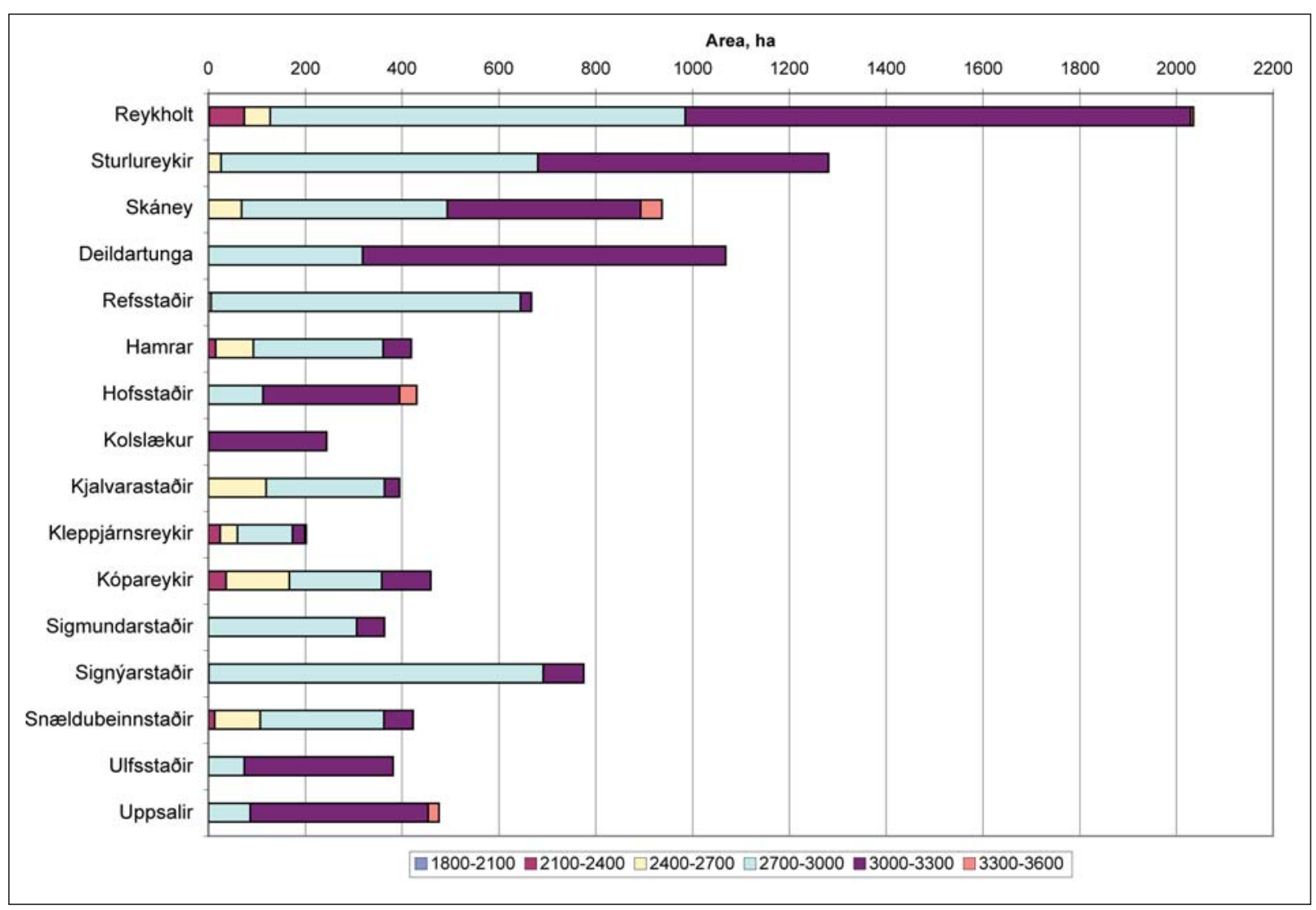

Figure 9. Area of settlement within each summer insolation class. The bar chart represents insolation class in $\mathrm{MJ} \mathrm{m}^{-2}$. 
indicate that permanent boundaries, such as rivers and gorges, were deciding factors in the initial partitioning process. Subsequent partitioning suggests that the initial landowner may have made an effort to ensure the viability of specialized livestock production within the area by allocating some of the best land to the second largest settlements, Skáney, Sturlureykir, and Deildartunga. The rest of the land was carved up into a set of smaller but still viable farms, some of which were subsequently taken over by the Reykholt estate.

The Reykholt estate did not hold the best land for intensive livestock production and does not seem to have practiced intensive management of its home-field areas, but certainly by the 15th century it had the largest land holding in the valley. This dominance may have been established at the outset, and it is becoming apparent that the farm was destined to take over the central role of power in the valley. This process was solidified by the establishment of a church and later a church center at Reykholt, paving the way for its development as a center of political and ecclesiastical power by the 12th century. Through the church, the estate acquired land and various resources that further enriched it, with documentary research showing that the possession of shieling areas (for summer milking livestock grazing) and other resources were vital for the later success of the estate.

\section{Acknowledgments}

We are grateful to the Leverhulme Trust for research support through the Landscapes circum Landnám program. John McArthur, Jennifer Brown, and Bill Jamieson (all at the University of Stirling) assisted with the GIS aspects of this paper.

\section{Literature Cited}

Alpingisbækur Íslands II (AI). 1915-16. Félagsprentsmiðjan, Reykjavík, Iceland.

Amorosi, T. 1996. Icelandic zooarchaeology: New data applied to issues of historical ecology, palaeoeconomy, and global change. Ph.D. Dissertation. The Graduate School and University Center of the City University of New York, New York, NY, USA.

The Árni Magnússon Institute for Icelandic Studies - The Place-Name Collection. No date. Hálsasveitarhreppur nr. 3509 Refsstaðir örnefnalýsing (place-name description for Refsstaðir), Ari Gíslason skráði, Reykjavík, Iceland.

Benediktsson, J. (Ed). 1968. Íslendingabók. Landnámabók, Íslenzk fornrit 1. Hið íslenska fornritafélag, Reykjavík, Iceland. 525 pp.

Benediktsson, J. 1996. Ritaðar heimildir um landnámið. Pp. 19-24, In G.Á. Grímsdóttir (Ed.). Um landnám á Íslandi. Vísindafélag Íslendinga, Ráđstefnurit V, Reykjavík, Iceland. 200 pp.
Byggðir Borgarfjarðar II. 1989. Borgarfjarðarsýsla og Akranes. B. Guðráðsson, and B. Ingimundardóttir (Eds.). Búnaðarsamband Borgarfjarðar, Borgarnes, Iceland. $400 \mathrm{pp}$.

Crawford, B.E., and B. Ballin-Smith 1999. The Biggings, Papa Stour, Shetland: The history and excavation of a royal Norwegian farm. Society of Antiquaries of Scotland Monograph Series, 15, Edinburgh, UK. 268 pp.

Diplomatarium Islandicum (DI). 1857-1952. Íslenskt fornbréfasafn. 16 vols. of Icelandic documents. S.L. Möller and Hið íslenska bókmenntafélag, Copenhagen, Denmark, and Reykjavík, Iceland.

Dixon, A.T.D.1997. Landnám and changing landuse at Háls, Southwest Iceland: A palaeoecological study. M.Sc. Thesis. University of Sheffield, Sheffield, UK.

Erlendsson, E. 2007. Environmental Change Around the Time of the Norse Settlement of Iceland. Unpublished Ph.D. Dissertation. University of Aberdeen, Aberdeen, UK.

Eypórsson, B. 2007. Búskapur og rekstur staðar í Reykholti. M.A. Thesis. University of Iceland, Reykjavík, Iceland. 125 pp.

Fellows-Jensen, G. 1984. Viking settlement in the northern and western isles. The place-name evidence as seen from Denmark and the Danelaw. Pp. 148-168, In A. Fenton and H. Pálsson (Eds.). The Northern and Western Isles in the Viking World. Survival, Continuity, and Change. John Donald, Edinburgh, UK. 347 pp.

Gammeltoft, P. 2001. The place-name element bólstaðr in the North Atlantic area. Navnestudier Nr. 38. Reitzel, Köbenhavn, Denmark.

Gathorne-Hardy, F.J., E. Erlendsson, J.M. Bending, K. Vickers, P.C. Buckland, A.J. Dugmore, B. Gunnarsdóttir, G. Gisladóttir, P. Langdon, and K.J. Edwards. In preparation. What was the impact of human colonisation in Reykholtsdalur, Borgarfjörður, Iceland?

Grönvold, K., N. Óskarsson, S.J. Johnsen, H.B. Clausen, C.U., Hammer, G. Bond, and E. Bard. 1995. Ash layers from Iceland in the Greenland GRIP ice core correlated with oceanic and land sediments. Earth and Planetary Science Letters 135:149-155.

Gunnlaugsson, G.M. (Ed.) 2000. Reykjaholtsmáldagi. Reykholtskirkja-Snorrastofa, Reykholt, Iceland. 48 pp.

Hermanns-Auardóttir, M. 1989. Islands tidiga bosättning. Studia Arshaeologica Universitas Umensis 1. Umeå, Sweden. 183 pp.

Jarðabók Árna Magnússonar og Páls Vídalíns. 1925 and 1927. Vol. 4. Copenhagen, Denmark. 497 pp.

Jóhannesson, J., M. Finnbogason, and K. Eldjárn (Eds.). 1946. Sturlunga Saga. 2 vols. Sturlungaútgáfan, Reykjavík, Iceland. $1110 \mathrm{pp}$.

Landamerkjabók Borgarfjarðarsýslu. Unpublished. Sýslumannsembættið Borgarnesi, Iceland.

Nordal, S. (Ed.). 1933. Egils Saga Skalla-Grímssonar, Íslenzk fornrit 2. Hið íslenska fornritafélag, Reykjavík, Iceland. 319 pp.

Nordal, S., and G. Jónsson (Eds) 1938. Borgfirðinga sögur, Íslenzk fornrit III. Hið íslenska fornritafélag, Reykjavík, Iceland. 365 pp. 
Olsen, M. 1928. Farms and fanes of ancient Norway: The place-names of a country discussed in their bearing on social and religious history. Instituttet for Sammenlignende Kulturforskning. Serie A: Forelesninger, 9. H. Aschenhoug and Co., Oslo, Norway, and Harvard University Press, Cambridge, MA, USA. 349 pp.

Pétursdóttir, D. 2002. Fornleifaskráning í Borgarfirði norðan Skarðsheiðar IV. Jarðir í Reykholtsdal og um neðanverða Hálsasveit. Fornleifastofnun Íslands FS158-00123, Reykjavík, Iceland. 149 pp.

Simpson, I.A.1997. Relict properties of anthropogenic deep top soils as indicators of infield management in Marwick, West Mainland Orkney. Journal of Archaeological Science 24:365-380.

Smith. K.P. 1995. Landnám: The settlement of Iceland in archaeological and historical perspective. World Archaeology 26(3):319-347.

Smith, K.P. 2005. Ore, fire, hammer, sickle: Iron production in Viking Age and Early Medieval Iceland. Pp. 183-206, In R.H. Bjork (Ed.). De Re Metallica: The Use of Metal in the Middle Ages. AVISTA Studies in the History of Medieval Technology, Science and Art, Vol. 4. Ashgate Publishing Limited, Aldershot, UK.

Steinnes, A. 1959. The "Huseby" system in Orkney. Scottish Historical Review 38:36-46.

Stylegar, F-A. 2002. Thorvald Thoresson, Sigrid Olaf'sdaughter and the SW Norwegian connection. Pp. 175-191, In B.E. Crawford (Ed.). Papa Stour and 1299. Shetland Times, Lerwick, Shetland. 205 pp.

Sveinbjarnardóttir, G. 1992. Farm abandonment in medieval and post medieval Iceland: An interdisciplinary study. Oxbow Monograph 17. Oxbow Books, Oxford, UK. 192 pp.

Sveinbjarnardóttir, G. 2004. Landnám og elsta byggð. Pp. 38-47, In Á. Björnsson and H. Róbertsdóttir (Eds.). Hlutavelta Tímans. National Museum of Iceland, Reykjavík, Iceland. 424 pp.

Sveinbjarnardóttir, G. 2005a. The use of geothermal resources at Reykholt in Borgarfjörður in the Medieval Period. Pp. 208-216, In A. Mortensen and S.V. Arge (Eds.). Viking and Norse in the North Atlantic. Select Papers from the Proceedings of the Fourteenth Viking Congress, Tórshavn, 19-30 July 2001. Annales Societatis Scientiarum Færoensis Supplementum XLIV, Tórshavn, Faroe Islands. 445 pp.

Sveinbjarnardóttir, G. 2005b. Reykholtssel. Fornleifarannsókn 2005. Vinnuskýrslur fornleifa 2005:4. National Museum of Iceland (National Museum of Iceland Reports), Reykjavík, Iceland.

Sveinbjarnardóttir, G. 2006. Reykholt: A centre of power: The archaeological evidence. Pp. 25-42, In E. Mundal (Ed.). Reykholt Som Makt- og lærdomssenter i den Islandske og Nordiske Kontekst. Snorrastofa, Menningar- og miðaldasetur, Reykholt, Iceland. 294 pp.

Sveinbjarnardóttir, G. In press. The making of a centre: The case of Reykholt, Iceland, In J. Sheehan and D.O Corráin (Eds.). The Viking Age: Ireland and the West. Proceedings of the 15th Viking Congress, Cork, 2005. Four Courts Press, Dublin, Ireland.
Sveinbjarnardóttir, G., E. Erlendsson, K. Vickers, T.H. McGovern, K.B. Milek, K.J. Edwards, I.A. Simpson, and G. Cook. 2007. The palaeoecology of a high status Icelandic farm. Environmental Archaeology 12(2): 197-216.

Vésteinsson, O. 1996. Menningarminjar í Borgarfirði norðan Skarðsheiðar. Svæðisskráning. Fornleifastofnun Íslands FS016-95033, Reykjavík, Iceland. 51 pp.

Vésteinsson, O. 1998. Patterns of settlement in Iceland: A study in pre-history. Saga Book 25:1-29.

Vésteinsson, O. 2000a. Fornleifaskráning í Borgarfirði Norðan Skarðsheiðar II. Reykholt og Breiðabólstaður í Reykholtsdal. Fornleifastofnun Íslands FS12600121, Reykjavík, Iceland. 41 pp.

Vésteinsson, O. 2000b. The Christianization of Iceland. Priests, Power, and Social Change 1000-1300. Oxford University Press, Oxford, UK. 318 pp.

Vésteinsson, O., T.H. McGovern, and C. Keller 2002. Enduring impacts: Social and environmental aspects of Viking Age settlement in Iceland and Greenland. Archaeologia Islandica 2:98-136.

porláksson, H. 2000. Icelandic society and Reykholt in the 12th and 13th century with special reference to Snorri Sturluson. Pp 11-20, In G. Sveinbjarnardóttir (Ed.). Reykholt in Borgarfjörður. An interdisciplinary research project. Workshop held 20-21 August 1999. National Museum of Iceland Research Reports, Reykjavík, Iceland.

pórðarson, M. 1936. Rannsókn nokkurra forndysja, o.fl. Árbók Hins íslenzka fornleifafélags 1933-1926: 28-46.

\section{Endnotes}

${ }^{1}$ A short history of the initial period of settlement in Iceland written in the first quarter of the $12^{\text {th }}$ century (Íslendingabók, xvii-xx).

${ }^{2}$ A chronicle of the $9^{\text {th }} / 10^{\text {th }}$ century settlement of Iceland, originally thought to have been compiled in the early $12^{\text {th }}$ century (e.g. Benediktsson 1996).

${ }^{3}$ Written in the first quarter of the $13^{\text {th }}$ century (Nordal 1933: lviii)

${ }^{4}$ At the time of writing this is inferred by stratigraphy rather than exact dates.

${ }^{5}$ Elevation is the height above mean sea level, influencing temperature. Slope describes steepness, influencing accessibility. Aspect refers to the direction a slope faces, and contributes to insolation. Insolation refers to the amount of solar energy received on a given area measured in MegaJoules (MG); summer insolation in this paper refers to the months June-September. Together these attributes influence seasonal and spatial patterns of vegeation productivity and diversity.

${ }^{6}$ Erdas Imagine 8.5: software allowing raw mapped data to be referenced to the ground.

${ }^{7}$ ArcInfo: a geographical information system (GIS) enabling overlaying of spatial data sets. 